\title{
フランスにおけるイラン研究とクルド研究
}

\section{Iranologie et Kurdologie en France}

\author{
山口昭 彦 \\ Y AMAGUCHI Akihiko
}

はじめに

本稿は，私が1993年夏より昨年秋までおよそ 3 年間，博士課程学生としてフランスに 滞在した際に得たささやかな経験から，この国におけるイラン研究とクルド研究の現状 について，その一端を報告しようとするものである。これまでにも，フランスのイラン 学に関しては羽田正氏が自身の留学経験をもとに学界紹介を行っておられるが，爾来す でに10余年の歳月が過ぎ，この間フランス学界も大きく様変わりしたこと，また，イラ ン学の一分野であるクルド研究の動向についてはわが国ではほとんど知られていないこ とから，氏の紹介文と重複する部分も多々あることを承知の上で，これらの研究分野の 動向について簡単な紹介を試みたい。なお, 報告者の関心がイスラム期のイラン地域, 特に歴史学にあるため, 紹介が自ずと偏ったものとなってしまったことをあらかじめお 断りしておきたい。

\section{I}

一般に，フランスにおける東洋学は，1795年の東洋諸語特別学校 École Spéciale des Langues Orientales Vivantes（後に触れる国立東洋言語文明学院の前身）の設立とと もに始まると言われる。そもそも，この学校は発足当初より，中東の主要 3 言語，すな わちトルコ語, アラビア語, ペルシャ語の講座がまず設けられたことから明らかなよう に，オスマン朝をはじめとする中東地域へのフランスの政治的経済的利害が設立動機と なっており，しかもその名称が示す如く，なによりもまず生きた言語の習得に主眼がお かれていた。しかしながら，少なくともイラン研究に関する限り，19世紀にあっては, もつぱら考古学とその成果に基づく古代イランに関する言語学的研究を中心に発展して いく。そこでは，同時代はもとより，イスラム期イラン社会の研究そのものがむしろ傍 流の地位にあり，十分な関心を引くことはなかったのである。このような状況を大きく 变え, あらゆる分野のイラン研究者を結集しながら, 古代から現代に至るまで, イラン

* 東京大学大学院博士課程

Étudiant de Doctorat, Université de Tokyo 
を時間的にも空間的にも総体として捉えようとする「イラン学」が一つの専門分野を形 成し始める出発点となったのが, 第 2 次大戦直後のイラン学研究所 Institut d'Études Iraniennes (パリ，1946）とその現地出先機関ともいうべきフランス・イラン研究所イ ラン学部門 Département d'Iranologie de l'Institut Franco-Iranien（テヘラン, 1947) の設置である。そして, 戦後のフランス・イラン学はこの 2 つの研究機関の充実化と歩 調を合わせながら発展していくのである。

現在, パリ第 3 大学の一角に居を構えるイラン学研究所の主な任務は, 同大学東洋・ アラブ世界学部における教育活動, 図書室の運営, 各種出版物の編集などである。

図書室には，イラン学関係の基本的工具類をはじめとして膨大な蔵書が集められてい る。およそ16,000の文献と1200定期刊行物をもつと言われる。ただ，門外漢故に言語 学や文学についてはわからないが, こと前近代イラン政治史に関する限り, 少なくとも 近年発行のものについては意外と手薄であるような印象を受けた。一方，近現代史につ いては昨今盛んに収集されているようである。また, 定期刊行物については, ペルシャ 語のものを中心にかなり充実したコレクションをもち，各雑誌の目次がすべて複写され てファイルにまとめられており，閲覧者の便宜が困られている。

今日のフランス研究所の前身テヘラン・フランス研究所イラン学部門は, 1947年にイ スラム思想史の大家 Henry Corbin によって，イランとの直接の接触・対話の場を確 保するという目的で設立されたものである。およそ20年ほど前にこの研究所によって， 書評誌 Abstracta Iranica が創刊されるが, この雑誌は, イラン人研究者に欧米にお けるイラン研究の動向を知らせると同時に，イラン国外に向けてイラン人研究者の業績 を伝えるという目的に基づくものであり，イランとの対話の場たろうとする当研究所の 創立理念をよく反映する活動と言えよう。

現在のフランス研究所 Institut Français de Recherche en Iran は, かつてのフラ ンス・イラン研究所イラン学部門が改組された Institut Français d'Iranologie en Téhéran と，1897年に De Morgan によって設立された Délégation Archéologique Française en Iran を合併改組することによって1983年に創設されたものである。イ ラン・イラク戦争中は運営に支障を来すこともあったが, 1989年以降は活発な活動を展 開するようになり，現在は，所長 Rémy Boucharlat 氏以下，およそ15名ほどの研究 者や職員が勤務し，研究活動に従事している。

なお，多くの在外研究施設がそうであるように，ここには宿泊設備が整えられており， フランス人のみならず各国の研究者に開かれている。また, フランス外務省の助成金に よりフランスあるいは欧州同盟諸国の国籍を有するもの，イラン出身者などを対象に， 研究者や博士課程の院生を数年単位で受け入れるなど, 現地との交流を重視するフラン 
ス・イラン学の伝統に沿う形で研究者の養成にも力が入れられている。

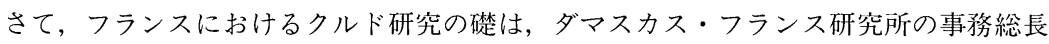
などを務めながら長年シリアに滞在し，ヤズィーディー教徒の研究などで大きな業績を 上げた Roger Lescot と, イラクのモースルにあってドミニコ会修道士として地域の キリスト教徒の教育に携わる中でクルド社会への関心を抱き, クルド文学やヤズィーディー 教徒について優れた研究を残した Thomas Bois によって築かれた。

彼らの跡を継いだのが，言語学と文学を専門とする Joyce Blau de Wangen 氏で あり，1970年代半ばにレスコーとブワが相次いで亡くなった後は，現在までフランスに おけるクルド研究を指導してきた人物である。氏は，これまで自らの専門分野である言 語学の分野で優れた論考を発表する傍ら, クルド人問題に関しても積極的に発言し，フ ランスが現在に至るまで政府や世論を含め，この問題に一定の関心を保っているのは氏 の努力によるところが大きいと言わねばならない。

上記以外の研究者としては, 自らイラン系クルド人で, もっぱら宗教や言語への関心 からアフレ・ハックの研究で数多くの業績を発表してきた Mohammad Mokri 氏, ト ルコ共和国におけるクルド人問題を特にケマリズムとの関連で追求する Hamit Bozarslan 氏，19世紀におけるナクシュバンディー教団のクルド人社会での活動を専門とする傍ら， 最近クルド語のソーラーニー方言とフランス語の辞書を発表した Halkawt Hakim 氏， イラン西部サナンダジュ周辺を14世紀以来19世紀半ばまで支配したアルダラーン一族に 関する博士論文を提出し, 以後も精力的にこの一族やその他クルド系名家に関する地方 史の発掘と校訂を手がけている Abdullah Mardukh 氏などがいる。

さて，フランスにおけるクルド研究を語るときに忘れてはならないのは，1983年にク ルド研究の奨励とクルド文化の保護を目的に設立されたクルド研究所 Institut kurde de Paris の存在である。フランス政府からの一定の財政援助を受けているとは言え, 基本的には非政府系機関であるクルド研究所は, 研究所とは言っても, 実際には情報セ ンターとしての性格が強く, クルド語教育の実施, 在仏クルド人の支援, クルド人問題 に関する世論を喚起するための宣伝活動が主な仕事となっている。図書室には，クルド 人問題をはじめとしてクルド史や文学に関する膨大な書籍が集められ，一般に開放され ている。2 次文献がほとんどであるが，クルド関係の書籍が一カ所に集められていると いう点では非常に便利である。研究所が1985年に創刊した学術雑誌 Studia Kurdica は, 当初, 英仏語, 及び中東の主要言語アラビア語, ペルシャ語, トルコ語で, 年 4 回 刊行するという予定を立てていたが，結局，スタッフの不足もあって，現在までのとこ ろわずかに 8 号までの刊行にとどまり，1993年をもって一時休刊のやむなきに至ってい る。 
もう一つ，フランスにおけるクルド研究において際だっているのが，頻繁な国際会議 の開催である。私が滞在していた間にも，1993年秋には「クルド語，2000年の地平に向 けて La langue kurde à l'horizon de l'an 2000」と題した会議が, それからさらに 3 年後の1996年秋には, 今度は「クルド人と都市 Les Kurdes et la cité」というテー マのもとに会議が開かれ，いずれも西欧諸国や現地イラクなどを中心に世界各国のクル ド研究者が一堂に会して, 活発な討論が交わされていた。これらの会議は, 主に上記ク ルド研究所とワンゲン氏の所属する国立東洋言語文明学院 (Institut National des Langues et Civilisations Orientales, 以下 INALCO) が主催者となって開かれたも のだが, フランスがクルド研究の分野において国際的にイニシアティブをとっていこう という姿勢を示すものと言える。

ここで,イラン学とクルド学に関するいくつかの図書館を紹介しておきたい。まず, イラン学関係の蔵書をもつ図書館としては, 国立図書館 Bibliothèque Nationale が, ペルシャ語写本や欧文旅行記などを中心に多くの文献をもつことでつとに知られている が，そのほかの主要図書館としてまず筆頭に挙げるべきは, INALCO の図書館であろ う。この図書館は, まさにフランス東洋学の 200 年にわたる歴史が刻み込まれたところ と言えるが, イラン学関係についても, 特にヨーロッパ人の旅行記やあるいは定期刊行 物のうち古いものはイラン学研究所ではなく，こちらにあることのほうが多いように思 う。また，クルド学関係についても，決して数は多くないものの，フランス国内ではク ルド研究所に次いで文献がそろっていると言える。次に挙げるべきは，19世紀から今世 紀前半を中心に旅行記や研究文献を豊富に有するソルボンヌ大学図書館と, 充実した定 期刊行物の蔵書をもつ Sainte Geneviève 図書館である。少なくとも歴史学に関する 限り, カルチェ・ラタンにあるこの 2 つの図書館で研究文献の大部分が見つかると言つ ても過言ではない。ただ，これはフランスの四書館一般に言えることではあるが，古い 文献については比較的充実しているが, 近年出版されたものに関しては, 必ずしも万全 な収集体制がとられているとは言いがたいことをつけ加えておく。

\section{II}

ここでは，研究グループとしてのエキップ制度について説明する。

エキップ制度とはフランスに固有な研究体制であるが, 一言で言うならば, 国立学術 センター Centre National de la Recherche Scientifique, 通称 CNRS ないしは大 学その他高等研究機関の管轄と財政援助を受けて研究に従事する研究グループであり, 研究者や一部博士課程学生を構成員とし, 定期的に会合を開きながら, 出版物の刊行, 学会の開催, あるいは研究費の配分などを行っている。 
「1995年版フランス・イラン学年鑑 Abstracta Iranica, Annuaire des Études Iraniennes en France, Deuxième edition, 1995, Institut Français de Recherche en Iran」に よれば，考古学から現代イラン研究まで，イラン学に何らかの関わりをもつエキップの 数は現在15以上に上っており，ここでそのすべてを逐一紹介する余裕はない。そこで， ここでは，フランス最大のイラン専門エキップとして，今後，好むと好まざるとに関わ らず，この国におけるイラン学の主流を形成していくであろう「イラン世界 Monde Iranien」研究エキップの構成とその活動の一端を提示することで, 現在のフランスに おけるイラン研究の大きな流れを示すことにしたい。

このエキップはかつて言語学者 G.Lazard 氏によって創設された「イランの言語, 文学, 文化 Langues, Littératures et Culture Iraniennes」研究エキップと, 人類学 者 J.-P.Digard 氏が率いていた「現代イラン世界の社会科学 Sciences Sociales du Monde Iranien Contemporain」研究エキップが，合体することにより1995年に設立 され, 現在地理学者 B.Hourcade 氏が幹事を勤めている。この研究グループは CNRS とパリ第 3 大学の管轄下にあって, イラン世界の諸文化と諸社会の総合的研究を目的と しており，イラン文化の総体的把握という戦後のフランスのイラン研究がめざした理念 の一つが行き着いた当然の帰結とも言える存在である。この研究グループには，30を越 える CNRS 所属の研究者, パリ高等研究院, 社会科学高等研究院, パリ第 3 , 第 4 , 第 7 , 第 8 大学, ランス大学, エクサン・プロヴァンス大学, ルーアン大学, そしてイ ラン・フランス研究所に属する研究者が参加している。

多彩な顔ぶれを抱えるこのエキップは，各人の研究テーマごとに次のような部会に分 かれている。

I イスラム以前のイラン世界の文明とその文化的伝統

1.ゾロアスター教の諸伝統 $: \mathrm{Ph}$. Gignoux

2. ササン朝及びイスラム期初期 100 年におけるイランの経済史及び貨幣史史料： R. Gyselen

3. 中世西部イラン語の歴史的文法と語彙記述学：P.Lecoq, Ph.Gignoux

II 文学, 哲学, 神秘主義

1. 文学上の人物と図像学的類型：C.Kappler, Y.Porter

2. 神秘主義文学と哲学：L.Chenderoff-Anvar, E.Pierunek, M.-A.Amir-Moezzi, P.Lory

III 歴史と文化

1.中世イランの社会史と文化史：D.Aigle

2. イラン世界における芸術と文化：Y.Porter, F.Richard, C.Adle, A.S.Melikian 
3. 近現代イランの政治文化史：H.Nategh, Y.Richard, F. Hellot

4. 非ペルシャ語の言語と文化：F.Balland, P.Lecoq

5. インド=ペルシャ文化：Y.Porter

IV イランの民族誌的文化的自然的遺産

1. 民族誌的遺産：J.-P.Digard, M.Bazin, S.Heslot, A.Tual, C.Bromberger, D. Balland

2. 科学と技術の歴史と民族学: Z.Vesel, P.Mohebbi, D.Gazagnadou

3. 秘術学と伝統的医学：N.Jozani, P.Lory, Z. Vezel

V アイデンティティー, 家族, ソシアビリテ

1.イランにおける家族と多産性：B.Hourcade, M.Ladier, N.Jozani

2. 社会化とアイデンティティー戦略：N.Yavari, A.Kian

3. イスラムと社会的再組織：F.Khosrokhavar

VI 新しい都市社会と経済発展

1. 大都市, 郊外, 都市社会: B.Hourcade, F.Khosrokhavar, M.Bazin

2. 国家と市場：T.Coville, F.Adelkhah

VII イラン世界の諸国家

1. 現代イラン国家の建設：Y.Richard

2. イラン世界の政治的構成：P.Tavernier

3. 中央アジアにおける政治的社会的再編：O.Roy

VIIII イラン世界とその隣人

部会の構成から，古代と近現代に関しては比較的充実した体制が敷かれているが，翻っ てイスラム期以降前近代までのイラン史に関しては，文化史をのぞいてやや手薄といっ た印象を否めない。エキップの実際の再編過程については部外者にはわからないが, 1980 年代初頭における学界動向を伝える羽田氏の紹介文と比較する限り, イラン関係エキッ プとして氏の挙げた 4 つのグループのうち，16世紀から19世紀を中心にイスラム世界を 特にヨーロッパとの関連で研究しようとした Jean Aubin 氏の研究エキップを除く 3 つがほぼここに吸収されたと考えられ，このような事情が，イスラム期イランの研究者 が「イラン世界」エキップに少ないことの理由の一端となっていると推測される。

さて,「イラン世界」エキップの活動は単に狭い意味での研究活動にとどまらない。 イラン学研究所の運営, パリ第 3 大学でのイラン関係の授業の実施, さらにはフランス 国内やヨーロッパにおけるイラン学にかんする，あるいはそれを含む学会の開催にも積 極的に参画するなど, きわめて多方面にわたり, イラン学研究所及びフランス研究所と 
三位一体となってフランス・イラン学を毫引する立場にある。

ところで, コンピュータによる研究環境の改善が叫ばれる現在, このエキップがイラ ン学研究所やフランス研究所との協力のもとに進めているプロジェクトの一つとして, イラン関係のあらゆる文献を網羅するデータベース, Data Iranica の作成が注目され る。Abstracta Iranica などの既存データを基礎に，1995年時点ですでに8000件の文献 が入力されているという。ちなみに，この成果の一部はすでに昨年秋の国際会議「クル ド人と都市」において, 「Les Kurdes et le Kurdistan, Bibliographie 1987-1996, par Martine Gillet et Marie-Madeleine Bériel」として配布された。

なお，残念ながら，クルド研究に特化するエキップは現在までのところ存在せず，た だ，各研究者がイラン関係やその他のエキップに参加あるいは協力するのみである。

\section{III}

次に, イラン学研究所発行のニューズレターに掲載されたイラン学関係授業一覧表を もとに，パリ地区で行われている大学院レベルのイラン学関係の授業を紹介する。ただ し，これはあくまでも当研究所が得た情報に基づくものであり，当然のことながらこの 表から漏れているイラン学関係の授業もあるものと予想される。

コレージュ・ド・フランス

G.Fussman：インド世界の歴史

J.Kellens：インド=イラン言語・宗教

G.Le Rider：ヘレニズム期オリエントの経済史

M.Tardieu：古代末期のシンクレティズム

社会科学高等研究院

V.Fourneau：モンゴル期以降中央アジアにおける空間，人口，民族的アイデンティ ティー

F. Khosrowkhavar：イランにおけるイスラム主義運動とイスラム革命

O.Roy：現代中央アジアにおける国家と社会

高等研究院第 4 部門,

J.Calmard：16世紀から18世紀における欧文史料に見るイラン像

P.Lecoq：中世イラン語文法入門

高等研究院第 5 部門

D. Aigle：ムスリム世界の宗教人類学

M.A.Amir-Moezzi：シーア派教義の歴史 
Ph.Gignoux, F.Grenet, CL.Herrenschmidt：古代イランの諸宗教

P.Lory：イスラム哲学史

ルーヴル校
A. Benoit：東洋考古学
F.Grillot：エラム語
P.Lecoq：古代ペルシャ語碑銘

パリ第 3 大学

M.A.Amir-Moezzi 及び P.Lory：イランの哲学的宗教的思想史

C.-H.de Fouchécour：古典文学

Y.Richard：近代史

\section{INALCO}

J.deWangen 及び A.Mardukh：近代クルド文学

Ch. Balay：ペルシャ語文学における短編

C.Poujol：中央アジア文明

このように，きわめて多岐に瓦るイラン学にかんする講義やゼミが開かれ，学生はイ ラン学の多様な分野にその専門家を通して接することができるわけである。もちろん， 大学間の垣根はそれなりにあって, 特に単位に関しては一部を除いて所属先の機関での 取得が義務づけられている。しかし，原則として毎年，登録機関を変更することが可能 であり，しかも，所属先に関わらず教官側も学生を自由に受け入れるため，各自が自ら の関心に従ってイラン学の様々な分野を専攻することが可能である。まさに，恵まれた 環境と言える。ただし，これはあくまでもパリに限ってのことであり，地方の場合には きわめて限定された選択肢があるのみと推測される。

ところで, 私は主として歴史学, 特に政治史や社会史に関心があったため, それらに 関する演習に参加していた。その際の印象として, イラン人学生が圧倒的多数を占め, いわゆるフランス人学生がわずか数人しかいないのには驚いたが，この背景には，おそ らく就職の問題があるように思われる。すなわち，もともとわずかな例外をのぞいて私 立大学が存在せず，国立大学だけでは教員のポスト数が限られている上に，かつてはそ の専門分野に関わらず若手研究者の受け㿼となっていた CNRS も現在ではきわめて門 戸が狭いなど，将来的な展望が必ずしも開けないことに原因があるように感じた。

また，昨今では学生の関心が近現代に向かうことが多いためか，たとえば，カージャー ル朝後半期を対象とするヤン・リシャール氏のゼミには，イラン人学生を中心に常時 10 人以上の出席者があったのに対し，イルハン朝からサファヴィー朝期のペルシャ語テキ 
ストの講読や欧人による旅行記についてのカルマール氏のゼミにはせいぜい 5 人ほどの 出席者しかいなかった。

このような傾向は，博士論文の提出状況にも反映している。最近では，イラン関係の 博士論文は，毎年コンスタントに13件程度が提出されている。残念ながらそのすべてを ここで紹介するわけにはいかないが，そこに見られる傾向は，学位請求者の大半がイラ ン系であることと，若干の例外を除いてすべてが近現代にかかわるテーマを扱ったもの で，中でも社会科学的な手法に基づくものが多いということである。なお，クルド関係 の博士論文は決して多くないが，近年提出されたものを見る限りほぼ同様のことが言え る。

最後に,クルド語の授業について一言触れておく。INALCO でのクルド語教育は, 第 2 次大戦後直後の1945年に早くも始まっており，欧米ではソ連に次いでもっとも早かっ たと言える。当初はロジェ・レスコーが講義を担当し，後に，シリア出身のクルド人 Kamuran Ali Bedirkhan に受け継がれた。はじめは, クルド語の北部方言であるク ルマーンジーのみが教授されていたが，1974年からは，南部方言ソーラーニーもまたワ ンゲン氏によって教えられるようになり，今日に至っている。現在では，文法と講読の ほか，ネイティブ・スピーカーによる会話の授業もあわせ，各学年ごとに週 8 時間の授 業が行われている。私が带在していた 3 年間についていうと, 出席者の多くが在仏クル ド人で，それ以外には人権運動に関心を持つフランス人，あるいは他のヨーロッパ諸国 からの留学生などが主で, いわゆる狭い意味でのフランス人学生の姿はほとんど見るこ とはなかった。このほかに, ワンゲン氏によって, クルド文学のゼミがごく少数の学生 を対象に開かれていた。なお, 博士課程レベルでのクルド研究, 特に歴史学や社会科学 に関する演習は存在せず, クルド人学生の多くは社会科学高等研究院や他の大学の政治 学関係のコースに登録するようである。

\section{おわりに}

以上，フランスにおけるイラン学とクルド学の動向について簡単に紹介してきたが, そこに見られる特徴は, ことイラン研究に関するかぎり, 現地イランの学界との対話の 重視と研究体制の高度な組織化の 2 点に集約されよう。そして, この 2 つの理念がそれ ぞれ，フランス研究所とイラン学研究所の活動に体現されてきたと言えるのである。し かも, かかる高度な組織化こそが, フランス・イラン学が, Studia Iranica や Abstracta Iranica など質の高い学術雑誌を発行して世界のイラン学をリードし, 同時にまた現地 出先機関を運営していくことを可能にしていると考えられるのである。

ただし，研究エキップの中には，「イラン」という枠組みにとらわれない形で，相異 
なる地域の尃門家が加わっているものもあり，必ずしも地域ごとに尃門特化しているわ けではないことを念のためつけ加えておく。また，わが国の中東学会に相当する AFEMAM (Association Française pour l'Etude du Monde Arabe et Musulman) なる学会が 1985年に設立され，イラン学研究所現所長ヤン・リシャール氏が副会長を務めており， イラン研究もまた広くイスラム地域研究という枠組の中に位置づけられ, 他地域の研究 者との相互交流の回路が開かれていることも忘れてはならないであろう。

もう一つ, フランスにおけるイラン学の発展において指摘すべきは, 政府機関の果た 寸役割である。現地出先機関の運営, 助成金の拠出, さらには研究者の現地への入国・ 滞在のための查証発給に関しても，外務省や在イラン大使館が積極的に便宜を図るなど， 研究の重要性に対する政府機関の哚い理解と協力がフランスにおけるイラン研究の発展 に大きく貢献してきたのである。このような状況には学問研究の政治からの独立性とい う点で賛否両論があろうが, イラン入国さえ容易ならざるわが国研究者のおかれた状況 を思うと、うらやましいと言わざるを得ない。

最後に，クルド研究に関して言えば，国際会議の開催など一見華々しい一面をもつも のの，実際には，イラン研究が制度化を着実に辿ってきたのとは対照的に，常勤ポスト に就く研究者がわずかに INALCO に 2 人，CNRS に 1 人いるのみで，学位をもった 優秀な研究者でさえポストが与えられていないという有り様である。しかも，これまで 学界の重鎮として活躍してきたワンゲン氏の定年も間近に迫っており，世代交代を進め ながらいかにポスト数を拡大するかが, 今後のフランスにおけるクルド研究の発展にと ク大きな課題となっているように感じた。

主要研究機関連絡先

Institut Français de Recherche en Iran (IFRI)

Directeur: Rémy Boucharlat

BP 15815-3495

Téhéran, Iran

Tel. (98-21)6401192/6403450

Fax. (98-21)640 5501

Institut d'Études Iraniennes (IEI)

Directeur: Yann Richard

Sorbonne nouvelle, UFR Orient et Monde Arabe

13, rue de Santeuil, 75231 Paris CEDEX 05 
tel. (33-1) 45874069

fax. (33-1) 45874170

Institut Kurde de Paris

106, rue La Fayette, 75010 Paris

tel. (33-1) 45231172

fax. (33-1) 47709904

注

（1）ただし，私個人の限られた見聞だけでは不十分なため，以下の文献を参照した。 羽田正，「フランスにおけるイラン学とトルコ学の現状」『東洋史研究』，42-4，1984, 167-173頁

Abstracta Iranica, Annuaire des Études Iraniennes en France, Deuxième edition, 1995, Institut Français de Recherche en Iran

Deux Siècles d'Histoire de l'École des langue orientales, Paris, 1995

Hakim, Halkawt, “À propos des études kurdes en France”, Les Annales de l'Autre Islam, État des lieux, perspective de recherche, No.1, Paris, 1993

Hourcade, Bernard, "Iranian Studies in France”, Iranian Studies, XX, 2-4, 1987, pp.1-51

Hourcade, Bernard, "La découverte de l'Iran Contemporain", Luqmân, 4,2, 1988, pp. 47-64

Institut d'Études Iraniennes, Études Iraniennes, Lettre d'Information, No.1 (mars 1995), No.2 (octobre 1995)

Richard, Yann, “L'Institut Français de Recherche en Iran”, Luqmân, 3,2, 1987, pp.11-22

（2）この国際会議について，詳しくは日本中東学会ニューズレターNo.66（1997年

3 月）揭載の拙稿を参照されたい。

Yamaguchi, Akihiko, "International Conference: The Kurds and the City",

JAMES Newsletter, No.66 (March 31, 1997), pp.7-11

（3）ただし，以下は1995年現在のものである。 